\section{Silica-Glass from the Libyan Desert}

A WIND-wORN lump of clear and transparent, pale yellowish-green silica-glass resembling bottle-glass from the Libyan Desert, has been presented to the Department of Minerals of the British Museum (Natural History) by the Survey of Egypt. This material has been recently discovered by Mr. P. A. Clayton of the Desert Surveys at latitude $25^{\circ} 20^{\prime} \mathrm{N}$., longitude $25^{\circ} 30^{\prime} \mathrm{E}$. (about 480 miles south-west of Cairo). It was found in considerable amount and over a wide area $(20 \mathrm{~km}$. by $20 \mathrm{~km}$.) as isolated pieces up to $10 \mathrm{lb}$. in weight in the hollows between the sand-dunes. It closely resembles the problematical glass long known from Bohemia and Moravia, which has been cut as a gem-stone under the names 'bottlestone' and 'water-chrysolite'. This is also known as moldavite and, with the australites ('blackfellow's buttons'), it is classed with the tektites, the origin of which is still obscure. The new glass from the Libyan Desert is found in much larger pieces and in greater quantity than any tektite yet known. It differs from the abundant silica-glass found last year by $\mathrm{Mr}$. Philby around the meteorite craters at Wabar in Arabia in showing an indication of flow structure and in the almost complete absence of bubbles; but it forms a very suggestive link between tektites and the silica-glass that has been definitely proved to have been formed by the fall of large meteorites.

\section{Botanical Acquisitions at the British Museum (Natural History)}

Mrss I. M. WRIGHT has presented to the Department of Botany of the British Museum (Natural History) the British herbarium of her father, C. A. Wright, which contains about 6,000 specimens. The interest of the collection is that it contains plants from several eminent botanists who used to send. them to Wright, as for several years he was unable to travel from his home at Kew on account of lameness. Dr. A. B. Rendle has recently been on a botanical trip to Jamaica and Bermuda and has brought back about 800 plants in which all the main groups are represented. The stay in Jamaica was short and collecting also suffered on account of the recent severe drought, but the collection as a whole is likely to prove of special interest. Dr. Rendle has been engaged for many years on the "Flora of Jamaica" and is therefore specially qualified to make the best use of what opportunities there were. The plants of Bermuda, accompanied by copious notes, will serve as an indication of the present state of the flora, from which many endemic species are being ousted by aliens.

\section{Colourless Generators of Anthocyanins}

IN continuation of their survey of the anthocyanins, Prof. and Mrs. Robert Robinson, in a paper recently published in the Biochemical Journal, have established the presence of a new class of colourless generators of anthocyanidins, which were first noted by Rosenheim and have been worked on to some extent by Jonesco. Such compounds are apparently quite widely distributed in plants: they require boiling with 10 per cent hydrochloric acid for a minute or so before they are converted into coloured anthocyanidin. Prof. and Mrs. Robinson are the first to recognise that the change is one of dehydration and not of oxidation, and to this extent the name leuco-anthocyanin suggested for the class is unfortunate. They assume that carbons 3 and 4 in the middle ring of the complex three-ring anthocyanidin formula both carry hydroxyl groups and that on dehydration there is loss of hydroxyl at 4 and hydrogen at 3. It is early yet to speculate on the significance of these compounds, which may be precursors of the anthocyanidins proper: their structure fits in with the theory that such compounds are derived from two and a half molecules of sugar. It is further of interest that many of the leucoanthocyanins listed are obtained from bark and wood. The new discovery shows that even the identification and the synthesis of the natural anthocyanins have not terminated the potentialities of this interesting field of inquiry.

\section{The Newcomen Society}

THE summer meeting of the Newcomen Society was held in Cornwall on June 13-16. On arrival at Falmouth, which was its headquarters, the members were received by the Mayor, Alderman J. Harris, and other members of the Council, and in the Municipal Building in which the reception took place, Mr. W. T. Hooper, the borough librarian, had arranged an exhibition relating to Cornish engineers and engineering. The meeting was devoted almost entirely to excursions to mines, foundries, enginehouses, china-clay works and places of interest with engineering associations, such as the houses in which Watt, Boulton, Trevithick, the Hornblowers and others lived from time to time. On behalf of the Society, the president, Mr. H. W. Dickinson, laid a wreath on the statue of Trevithick in Camborne and at St. Gluvias Church, Penryn; Mr. Hooper gave a short account of the work of the Hornblower family, one of whom, Jonathan Hornblower, was a pioneer of the compound steam engine. Although in many parts of the county are still to be seen fine specimens of 'Cornish' engines, the extension of the 'grid' will soon lead to these falling into disuse, electrically driven pumps being particularly suited for much of the work.

\section{Spectroscopic Conference at Massachusetts Institute of} Technology

ThE programme for the Spectroscopic Conference to be held at the Massachusetts Institute of Technology, Cambridge, Mass., on July 17-21 has recently been issued. The following topics will be discussed : quantitative spectroscopic analysis of materials, Dr. C. E. K. Mees, Dr. W. F. Meggers, Mr. C. C. Nitchie and Mr. F. Twyman; biological and photochemical applications of spectroscopy, Prof. G. B. Kistiakowsky, Mr. P. A. Leighton, Mr. W. A. Noyes and Mr. F. Twyman; physical and astrophysical aspects of spectroscopy, Prof. F. H. Crawford, Prof. G. H. Dieke and Prof. D. H. Menzel ; analysis of complex spectra, Dr. K. Burns, Prof. G. H. Dieke, Dr. W. F. Meggers 
and Prof. A. G. Shenstone; spectroscopy and atomic structure, Prof. G. R. Harrison, Prof. D. R. Hartree and Prof. J. C. Slater. Only the mornings are to be occupied with these topics, the afternoons being left free for informal discussions, the inspection of laboratories, etc. The Conference, it should be noted, is merely the central feature of a summer research gathering of spectroscopists which it is hoped will become an annual feature of the Institute's programme. Already this year a number of investigators have stated their intention of spending some time investigating specific problems with the very complete spectroscopic equipment now available at the Institute.

\section{The British Electrical and Allied Manufacturers' Associ- ation ('Beama')}

The 'Beama' (Kingsway, London, W.C.2) has recently published a book entitled "Twenty-One Years" which gives an interesting review of the work done by the British Electrical and Allied Manufacturers' Association since it was founded in 1911. The founders thought that voluntary co-operative action would go far to meet the economic difficulties which at that time were proving a severe handicap to the development of the electrical industry in Great Britain. Practically all the electrical manufacturers in the country are members of this Association. It has done excellent work in introducing order into the commercial relations between its members and its customers. Its opinion has carried great weight when legislation affecting the industry has been proposed. It has promoted far-reaching policies of research and standardisation benefiting engineering in general. The principle behind the Association's activities has been co-operation without the sacrifice of individual initiative. It has succeeded in linking together the manufacturing interests with the leading professional engineering institutions. Mr. D. N. Dunlop has been the director of the Beama since its start and much of its success is due to him. It has done excellent work in providing for the education in Great Britain of students from all countries, particularly from the Dominions. In 1920 it founded a research association which has done excellent work. During the past few years electrical manufacturers have begun to increase their exports to Europe, a sign of competitive efficiency. The Association took a leading part in encouraging the World Power Conference and also in encouraging the National Grid Scheme, the largest electrical achievement in the world.

\section{The National Physical Laboratory}

THE report of the National Physical Laboratory for the year 1932 is an illustrated volume of 277 pages which gives a short account of the activities of each department of the Laboratory. Owing to the trade depression, the number of investigations carried out for industry and the number of routine tests have fallen off, and the resulting diminution of income has necessitated reduction of expenditure on materials and equipment, and leaving vacancies on the staff caused by resignations unfilled. The new tank for ship tests has been completed, the acoustics building is nearly ready and the new wind tunnel for high speed tests is well in hand. The erection of the photometry building has been postponed. A gift of $£ 5,000$ has been received from Sir James Lithgow for a propeller water tunnel in the Froude Laboratory. In addition to eighty reports and memoranda on aerodynamical subjects, ninety-one official and twenty unofficial papers on other branches of the work of the Laboratory have been published in scientific and technical journals during the year, and they afford ample evidence that the Laboratory is taking a prominent part in the advance of sicience and industry.

\section{Physics in American Industry}

In connexion with an editorial note in the April issue of the Review of Scientific Instruments, American manufacturers are urged to keep in touch with the fundamental science of physics in all industries which deal with the mechanical and electrical properties of materials, the flow of heat, the use of colour and the reproduction of sound : and some useful information is given as to the means at present available for securing this contact. The Review, which is published monthly, goes free to every member of five scientific societies and at a reduced subscription to any person who already subscribes to one of the seven other journals dealing with physics, which are published in the United States. A large proportion of the five to six thousand copies of the Review goes into the hands of people associated in one way or other with manufacturers, but the editors consider that in the interest of industry many more copies should be utilised in this way. It is hoped that the association of local physical societies with the recently formed American Institute of Physics will help to link physics and industry more closely throughout the United States.

\section{Science and Education in Poland}

THE two outstanding contributions in vol. 16 of Nauka Polska, an annual publication devoted to studies in science and letters in Poland, are "The New Trends in Scientific "Thought" by Prof. C. Białobrzewski and "The Promotion of Education in the Provinces of Podolia, Volhynia and the Ukraine before the Partition of Poland" by Prof. A. Knot. Prof. Bialobrzewski is concerned mainly with the philosophical outlook and with recent developments in psychology, but he also remarks upon the progress now taking place in various branches of physics. $\mathrm{He}$ asserts that one epoch in the history of science has just closed and that another, more definitely creative, is beginning. Prof. Knot's account of the early educational facilities in south-east Poland is a well-documented article. The author has traced the development of educational institutions in these remote districts from the fourteenth century to the close of the eighteenth, when the kingdom of Poland was completely partitioned between Russia, Prussia and Austria. Mention is also made in this number of Nauka Polska of the celebrations held at Warsaw last year, commemorating the fifty years' existence of the Mianowski Institute. Among the notes from 